\title{
Correlation between Serum Neutrophil Gelatinase Associated Lipocalin and Burn Severity: A Pilot Study
}

\author{
Sungjun Lee', Suyeol Lee', Youngwhan Choi'², Song Vogue Ahn ${ }^{3}$, Cheonjae Yoon², Jungsuk Lee ${ }^{{ }^{*}}$ \\ ${ }^{1}$ Bestian R \& D Center, Medical Group Bestian, Daejeon, Korea \\ ${ }^{2}$ Department of Emergency Medicine, Bestian Seoul Hospital, Seoul, Korea \\ ${ }^{3}$ Department of Preventive Medicine, Institute of Genomic Cohort, Wonju College of Medicine, Yonsei University, Wonju, Korea \\ Email: *nostalgie@naver.com
}

How to cite this paper: Lee, S., Lee, S., Choi, Y., Ahn, S.V., Yoon, C. and Lee, J. (2017) Correlation between Serum Neutrophil Gelatinase Associated Lipocalin and Burn Severity: A Pilot Study. Journal of Biosciences and Medicines, 5, 11-25. http://dx.doi.org/10.4236/jbm.2017.51002

Received: September 6, 2016

Accepted: January 2, 2017

Published: January 5, 2017

Copyright $\odot 2017$ by authors and Scientific Research Publishing Inc. This work is licensed under the Creative Commons Attribution International License (CC BY 4.0).

http://creativecommons.org/licenses/by/4.0/

\section{(c) (i) Open Access}

\begin{abstract}
The severity of an initial burn injury is critical for determining the treatment plan and prognosis of burn patients. Here, we measured serum neutrophil gelatinase-associated lipocalin (NGAL) levels to determine whether NGAL can be used as a biomarker for severity of burn injuries. A study of the demographic, clinical, and laboratory markers for various organ damage was performed at Bestian Burn Center ( $\mathrm{n}=10$ healthy people, $\mathrm{n}=31$ patients). NGAL and organ damage marker levels were measured in 31 patients with severe burns within 2 - 3 days following their admission to the intensive care unit. Serum NGAL level of the expired patients was $788.5(685.0$ - 998.0) $\mathrm{pg} / \mathrm{mL}$, whereas that of the discharged patients was $421.2(356.2-480.6) \mathrm{pg} / \mathrm{mL}$, showing that the initial serum NGAL level can be used to estimate mortality. We also determined the correlation between serum NGAL level and the currently used severity markers (total body surface area burned and abbreviated burn severity index) and confirmed that serum NGAL level could be used as a severity marker. We also found that serum NGAL level was correlated with damage of organs such as the liver, kidney, heart, and respiratory organs in patients with severe burns.
\end{abstract}

\section{Keywords}

Serum Neutrophil Gelatinase-Associated Lipocalin, Total Body Surface Area, Abbreviated Burn Severity Index, Organ Damage, Prognosis of Burns

\section{Introduction}

In humans, following skin damage and infection, various types of reactions pre- 
vent tissue damage and activate the recovery process to restore organ functions. The acute-phase response begins at the injured sites where the circulatory plasma protein level changes when a soluble mediator is released, which in turn induces a metabolic and inflammatory response in organs [1]. NGAL is a lipocalin family protein and exists in the disulfide-bond form of a $25-\mathrm{kDa}$ homodimer, lipocalin 2, and a 135-kDa molecule, neutrophil gelatinase [2] .

The secretion of NGAL is activated by lactoferrin and vitamin $B_{12}$, and its expression increases in epithelial cells in the inflammatory state. NGAL is secreted mainly from neutrophils as well as various organs including the kidney, liver, lung, and bronchus. NGAL has antibacterial effects, thus playing a critical role in early bacterial infection [3] [4] [5]. During bacterial invasion, the toll-like receptor stimulates the transcription, translation, and secretion of NGAL. Secreted NGAL isolates the siderophore, including iron, which in turn inhibits bacterial growth [6]. Additionally, NGAL is known to help control homeostasis in various diseases in addition to inflammation [7] [8], body temperature [9], and plasma glucose levels [10].

NGAL expression is low in the normal state but increases rapidly in an acute inflammatory response [11] [12]. A previous study reported that expression of the inflammatory acute-phase response gene LCN2 increases in the liver of rats 8 hours after burn injury [13]. Human NGAL is a component of neutrophil granules, but it is expressed in epithelial cells through an inflammatory response [5]. Previous studies have reported that the increase in NGAL expression is more significant in severe sepsis than in uncomplicated sepsis. Further, NAGL reportedly has a protective effect in different conditions such as cold and heat stress and $\mathrm{H}_{2} \mathrm{O}_{2}$ toxicity and on various organs [14] [15] [16]. Some clinical studies reported that NGAL was used as a biomarker for renal failure to detect acute kidney damage in early-stage burn injury, and the NGAL level increased in the burn patients with acute kidney injury (AKI) 7 days after injury [17].

After acute injury in patients with severe burns, several pathophysiological changes occur following skin tissue damage by heat and acute systemic disease due to burn shock and production of inflammatory mediators. The prognosis of such burn patients is influenced by age, gender, injured area, size of burn injury, existence of other diseases, cause of injury, and presence of respiratory injuries. Therefore, accurate and objective evaluation of severity is critical to determine appropriate treatment for burn patients [18].

The severity of burn injuries can be evaluated by a number of methods including measurement of the Acute Physiology and Chronic Health Evaluation II (APACHE II) score, TBSA and ABSI. Although only the ABSI classifies burn patients on the basis of five variables, others are low as its clinical applicability [19]. To verify the value of NGAL as a marker for the diagnosis and prognosis of burn injuries in the early stage, we compared the differences in serum NGAL levels, including initial NGAL level, between ICU patients who were discharged and those who died. 


\section{Materials and Methods}

\subsection{Study Design and Population}

We conducted an observational study in the emergency department and intensive care unit (ICU) of Bestian Medical Center (Seoul and Daejeon, Republic of Korea) between August 2012 and May 2014. This study was performed with standard of selection. All consecutive patients aged $\geq 18$ years and $<65$ years with a flame burn involving $\geq 25 \%$ of the TBSA. Patients were admitted to the Bestian Medical Center within 12 hours of their injury, were included in the study.

Of 45 patients assessed, 31 patients were included in the study. The exclusion criteria were as follows: age $<18$ or $\geq 65$ years, burn size $<25 \%$ of the TBSA, other concomitant trauma, diabetes, and hypertension. Ten healthy subjects were included in the control group. Further, we evaluated the following parameters that could have influenced the mortality rate: age, sex, cause of burn, burn size, presence of inhalational injury, number of surgeries, length of stay in the ICU and hospital, and TBSA. We assessed serum NGAL \& clinical levels in both patients and control subjects. The patient group was further divided into expired patients and discharged patients. The study protocol was approved by the Institutional Review Board of Bestian Hospital.

\subsection{Clinical Data Collection, Follow-Up, and NGAL Measurements}

Initial clinical data were measured at medical-surgical ICU within 12 hours after the burn occurred. Additional blood samples for serum NGAL were collected every 2 days from the ICU patients and every 2 days from a general ward patients for the duration of the study. Blood samples were no longer collected after a patient left the hospital or died. Blood samples were collected and processed within 1 hour from the time of collection. We acquired serum samples from 10 healthy human subjects and 31 burn patients. The samples were centrifuged at $3000 \mathrm{rpm}$ for 15 minutes (Hanil Sciences, Korea) and immediately stored at $-80^{\circ} \mathrm{C}$ until analysis.

Serum NGAL levels were measured using an ELISA kit (Bioporto, Denmark) with an assay range of $10-1000 \mathrm{pg} / \mathrm{mL}$. Based on the ELISA results, samples were diluted 500 -fold. Briefly, $100 \mu \mathrm{L}$ of the sample was added to the antibodycoated microwell and incubated for 60 minutes at room temperature on a shaking platform. The plate was washed four times, after which $100 \mu \mathrm{L}$ of biotinylated NGAL antibody was added. The plate was incubated again for 60 minutes at room temperature on a shaking platform, followed by washing four times again. Subsequently, $100 \mu \mathrm{L}$ of 3, 3', 5, 5'-tetramethylbenzidine substrate was dispensed into each microwell and incubated for 10 minutes at room temperature in the dark. The reaction was stopped by adding $100 \mu \mathrm{L}$ of stop solution. Colorimetric analysis was performed using a Spectra Max Micro Plate Reader (Molecular Devices, CA) at $450 \mathrm{~nm}$. For comparative purposes, serum NGAL levels were measured in anticoagulated plasma of apparently healthy donors. We evaluated the changes serum NGAL level for 35 days or until death or discharge from the hospital. Baseline clinical data included hemodynamic parameters, serum lactate le- 
vels, and heart, renal, and liver function.

\subsection{Laboratory Measurements}

The following characteristics of patients with severe burns in each group were analyzed: age, sex, and number of hospitalization days. In addition to the ABSI and percentage of TBSA burned, the following levels were measured in serum: aspartate aminotransferase (AST), alanine aminotransferase (ALT), total bilirubin, blood urea nitrogen (BUN), creatinine, lactic dehydrogenase (LDH), creatinine phosphokinase, $\mathrm{C}$-reactive protein (CRP), protein, myoglobin and amlyase. We examined a retrospective analysis of burn patients who had measurement of these factors within 48 hours of injury and healthy subjects center at the Bestian Medical Center.

\subsection{Ethics and Statistical Analysis}

The study was reviewed and approved by the Institutional Review Board of the Bestian Seoul Burn Center, Seoul, Korea.

Analysis of variance with Spearman correction, paired and unpaired $\chi^{2}$ tests, and Mann-Whitney tests were used for analysis. Data are expressed as mean \pm standard deviation or standard error of the mean. Values of $p<0.05$ were considered statistically significant.

\section{Results}

\subsection{NGAL Expression in ICU Burn Patients}

All demographic data are presented in Table 1 . The average age was 43.48 years; $87 \%$ were men and $13 \%$ were women. The average TBSA burned was $46 \%$. The mortality rate was approximately $45 \%$ (14/31). Initial NGAL levels were measured at the Bestian Hospital ICU within 48 hours after the burn occurred. The mean of serum NGAL level was significantly higher in the expired patients compared with those who were discharged $(788.5 \mathrm{pg} / \mathrm{mL}[\mathrm{n}=14]$ vs. $421.2 \mathrm{pg} / \mathrm{mL}[\mathrm{n}$ = 17], respectively; $\mathrm{p}<0.001 ;$ Table 1 ).

Serum NGAL levels were significantly higher in the patient group $(611 \mathrm{pg} / \mathrm{mL})$ compared with the control group $(174 \mathrm{pg} / \mathrm{mL})(\mathrm{p}<0.001)$ and in the expired patients $(788.5 \mathrm{pg} / \mathrm{mL})$ compared with the discharged patients $(421.2 \mathrm{pg} / \mathrm{mL})(\mathrm{p}<$ 0.001) (Figure 1). If serum NGAL level decreased over time, the burn patient was moved to the general ward or discharged; however, if serum NGAL level increased or remained high and unchanged, the patient usually died or stayed in the ICU for a long period.

\subsection{Patient Demographics and Laboratory Measurements}

Regarding hospital stay, the expired patients had a shorter stay than the discharged patients. Along with serum NGAL levels, the mean TBSA and AST, LDH, and myoglobin levels were significantly higher $(\mathrm{p}<0.001)$ in the expired patients than in the discharged patients: TBSA, $66.5 \%$ vs. $30.0 \%$; AST, $68 \mathrm{IU} / \mathrm{L}$ vs. $31 \mathrm{IU} / \mathrm{L}$; LDH, 527 IU/L vs. 290IU/L; myoglobin, $311 \mathrm{ng} / \mathrm{ml}$ vs. $62 \mathrm{ng} / \mathrm{ml}$. 
Table 1. The patient demographics of discharge \& expire groups.

\begin{tabular}{|c|c|c|c|c|}
\hline & Normal Range & Discharged $(\mathrm{n}=17)$ & Expired $(\mathrm{n}=14)$ & $\mathrm{p}$ \\
\hline Age, years & & $44.9 \pm 13.5$ & $41.9 \pm 16.6$ & 0.58 \\
\hline Male, N (\%) & & $14(82.4)$ & $13(92.9)$ & 0.607 \\
\hline $\begin{array}{c}\text { Duration of } \\
\text { hospitalization }{ }^{\mathrm{a}} \text {, days }\end{array}$ & - & $61(30,75)$ & $7.5(6.0,12.0)$ & $<0.001$ \\
\hline Number of surgery ${ }^{a}$ & - & $2(1,4)$ & $1(1,2)$ & 0.418 \\
\hline $\mathrm{TBSA}^{\mathrm{a}}$ & - & $30.0(22.0,44.0)$ & $66.5(50.0,78.0)$ & $<0.001$ \\
\hline $\mathrm{ABSI}^{\mathrm{a}}$ & - & $8(6,9)$ & $11(9,12)$ & 0.002 \\
\hline $\mathrm{NGAL}^{\mathrm{a}}(\mathrm{pg} / \mathrm{mL})$ & 157.1 & $421.2(356.2,480.6)$ & $788.5(685.0,998.0)$ & $<0.001$ \\
\hline BUN (mg/dL) & $8 \sim 20$ & $14.2 \pm 4.7$ & $17.3 \pm 7.7$ & 0.176 \\
\hline Creatinine $(\mathrm{mg} / \mathrm{dL})$ & $0.8 \sim 1.2$ & $0.88 \pm 0.18$ & $0.97 \pm 0.26$ & 0.3 \\
\hline $\operatorname{AST}^{\mathrm{a}}(\mathrm{IU} / \mathrm{L})$ & $8 \sim 38$ & $31(23,37)$ & $68(50,75)$ & $<0.001$ \\
\hline $\operatorname{ALT}^{\mathrm{a}}(\mathrm{IU} / \mathrm{L})$ & $4 \sim 44$ & $22(18,29)$ & $28(17,47)$ & 0.203 \\
\hline $\mathrm{GGT}^{\mathrm{a}}(\mathrm{IU} / \mathrm{L})$ & $16 \sim 73$ & $22(19,78)$ & $44(22,86)$ & 0.506 \\
\hline Total bilirubin $^{a}$ & $0.1 \sim 1.20$ & $0.67(0.50,1.00)$ & $0.85(0.50,1.60)$ & 0.371 \\
\hline $\mathrm{LDH}^{\mathrm{a}}(\mathrm{IU} / \mathrm{L})$ & $106 \sim 211$ & $290(214,353)$ & $527(391,651)$ & $<0.001$ \\
\hline $\mathrm{CPK}^{\mathrm{a}}(\mathrm{IU} / \mathrm{L})$ & $43 \sim 165$ & $208.5(168.0,320.0)$ & $277.5(230.0,540.0)$ & 0.148 \\
\hline $\operatorname{Protein}^{\mathrm{a}}(\mathrm{mg} / \mathrm{L})$ & $1.0 \sim 3.0$ & $6.2(6.0,6.6)$ & $5.2(3.6,6.2)$ & 0.012 \\
\hline $\mathrm{CRP}(\mathrm{g} / \mathrm{dl})$ & $5.8 \sim 8.1$ & $61.5(10,98)$ & $89.7(46,95)$ & 0.234 \\
\hline $\begin{array}{c}\text { Amylase }\left(\mathrm{T} \_ \text {amylase }\right)^{\mathrm{a}} \\
\qquad(\mathrm{IU} / \mathrm{L})\end{array}$ & $43 \sim 116$ & $50(41,74)$ & $42(25,53)$ & 0.347 \\
\hline $\mathrm{pO}_{2}(\mathrm{mmHg})$ & $80 \sim 100$ & $128(95.1,165.3)$ & $194(100.2,208.4)$ & 0.418 \\
\hline Myoglobin (ng/ml) & $10 \sim 95$ & $62(46.5,77.3)$ & $311(156.2,804.3)$ & 0.001 \\
\hline
\end{tabular}

Values are expressed as mean \pm SD or number (percentage). ${ }^{\text {a } V a l u e s ~ a r e ~ e x p r e s s e d ~ a s ~ m e d i a n ~(l o w e r ~}$ quartile-upper quartile). $\mathrm{p}$ value from Mann-Whitney $\mathrm{U}$ test.

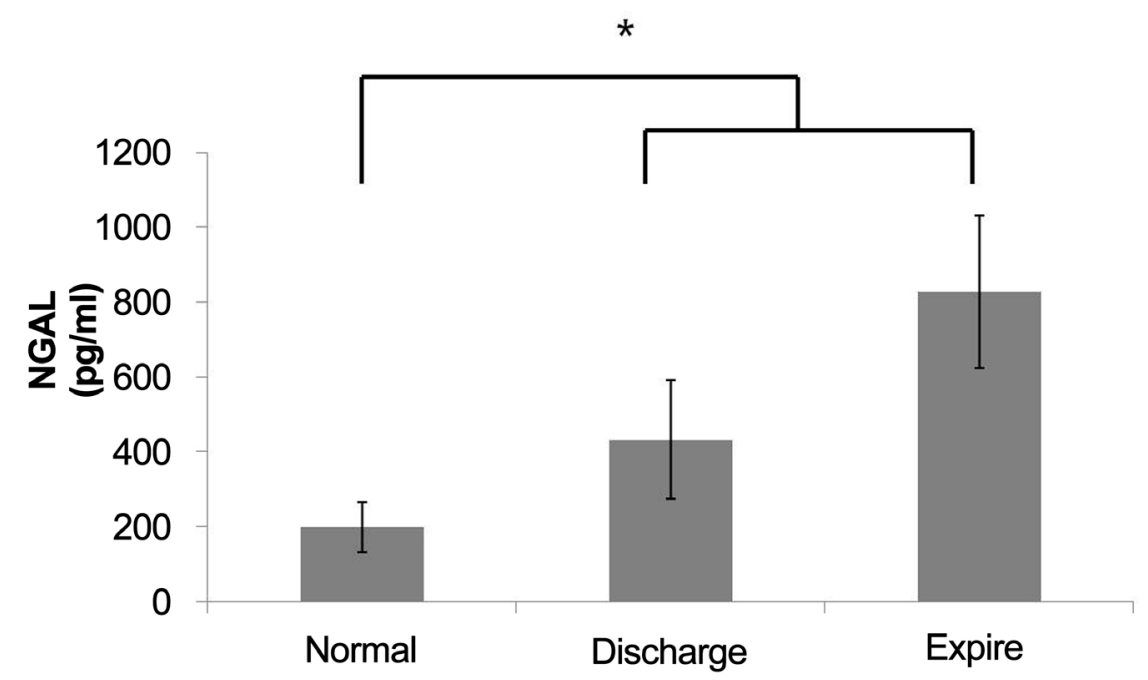

Figure 1. The average of NGAL expression in normal, discharge and expire groups. Significant difference between discharge/espire group versus nomal range; ${ }^{\star} \mathrm{p}<0.001$. 


\subsection{Correlation between NGAL Levels and Laboratory Parameters}

Spearman correlation analysis revealed correlations between serum NGAL levels and each laboratory parameter was evaluated in all patients (Table 2). Serum NGAL level was significantly positively correlated with TBSA $(r=0.572, p=$ $0.001)$, ABSI $(r=0.503, p=0.004)$, and AST $(r=0.526, p=0.002)$, LDH $(r=$ $0.58, \mathrm{p}<0.001)$, and myoglobin $(\mathrm{r}=0.559, \mathrm{p}=0.001)$ levels (Table 2$)$. The scatter plots in Figure 2 reveal relationships or associations between two scores (TBSA vs. NGAL and ABSI vs. NGAL).

\subsection{Long-Term Expression of NGAL in Burn Patients}

Serum NGAL levels in the expired patients remained consistently high for 5 - 35 days (until death). Serum NGAL levels in the survival group were initially high but decreased slightly within 14 days or increased temporarily but eventually decreased again (Figure 3).

\subsection{NGAL Levels and Mortality}

A logistic regression analysis with odds ratios was performed using TBSA, ABSI, and serum NGAL levels with death as a dependent variable. TBSA, ABSI, and

Table 2. The correlation of NGAL and other factors.

\begin{tabular}{|c|c|}
\hline Factors & All patients $(n=31)$ \\
\hline Age & $-0.115(0.537)$ \\
\hline Duration of hospitalization, Day & $-0.403(0.025)$ \\
\hline Number of surgery & $-0.017(0.928)$ \\
\hline TBSA & $0.572(0.001)$ \\
\hline ABSI & $0.503(0.004)$ \\
\hline BUN & $0.280(0.128)$ \\
\hline Creatinine & $0.188(0.312)$ \\
\hline AST & $0.526(0.002)$ \\
\hline ALT & $0.352(0.052)$ \\
\hline GGT & $0.010(0.957)$ \\
\hline Total bilirubin & $0.071(0.703)$ \\
\hline $\mathrm{LDH}$ & $0.580(<0.001)$ \\
\hline $\mathrm{CPK}$ & $0.200(0.307)$ \\
\hline Protein & $-0.348(0.055)$ \\
\hline CRP & $0.331(0.069)$ \\
\hline Amylase & $-0.063(0.743)$ \\
\hline $\mathrm{pO}_{2}$ & $0.204(0.281)$ \\
\hline Myoglobin & $0.559(0.016)$ \\
\hline
\end{tabular}

Values are expressed as Spearman's correlation coefficients ( $\mathrm{p}$ value). 

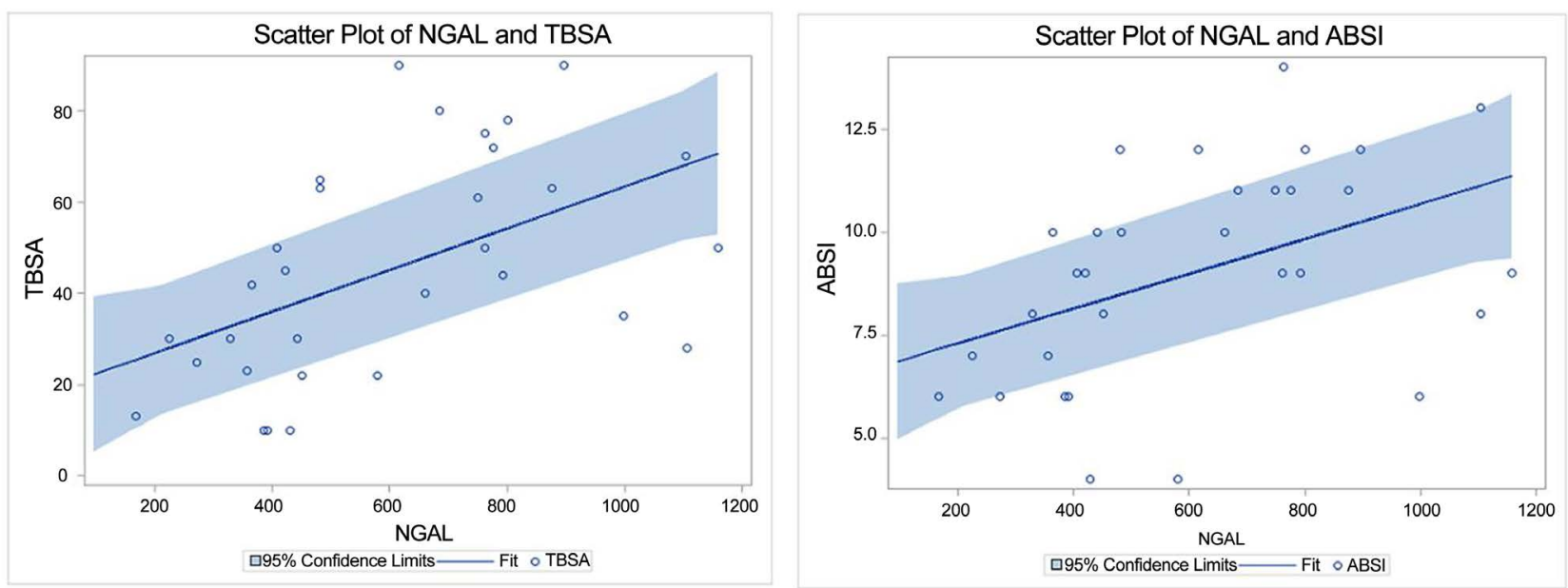

Figure 2. The analysis of scatter plot TBSA versus NGAL \& ABSI versus NGAL.

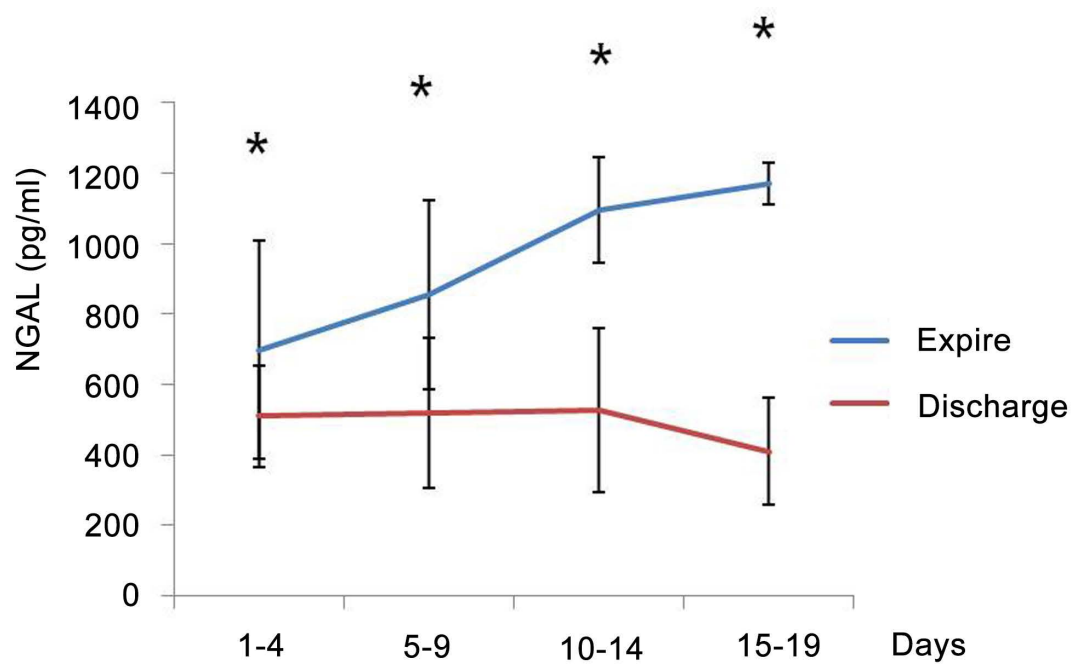

Figure 3. The difference of NGAL level of expire group and discharge group. Significant difference between expire group versus discharge group: ${ }^{\star} \mathrm{p}<0.005$.

serum NGAL levels were statistically correlated $(\mathrm{p}<0.05)$. As the TBSA and ABSI levels increased by 1 unit, the odds ratio increased 1.085 times and 1.884 times, respectively. In contrast, as serum NGAL increased by 10 units, the odds ratio increased 1.109 times (Table 3). Serum NGAL levels compensated for age, TBSA, and ABSI. The results of the multiple logistic regression indicated a statistically significant increase in the mortality risk as serum NGAL level increased by 10 units.

\subsection{NGAL for the Prediction of Organ Damage after a Burn}

To determine the correlation between serum NGAL levels and AKI, we comparatively analyzed factors associated with kidney damage. The BUN level remained within the normal range $(8-25 \mathrm{mg} / \mathrm{dL})$ in the discharged patients, but in expired patients, it eventually increased 10 days after the burn injury (Figure 4) Serum NGAL levels rapidly increased within 3 days of injuries, whereas the 

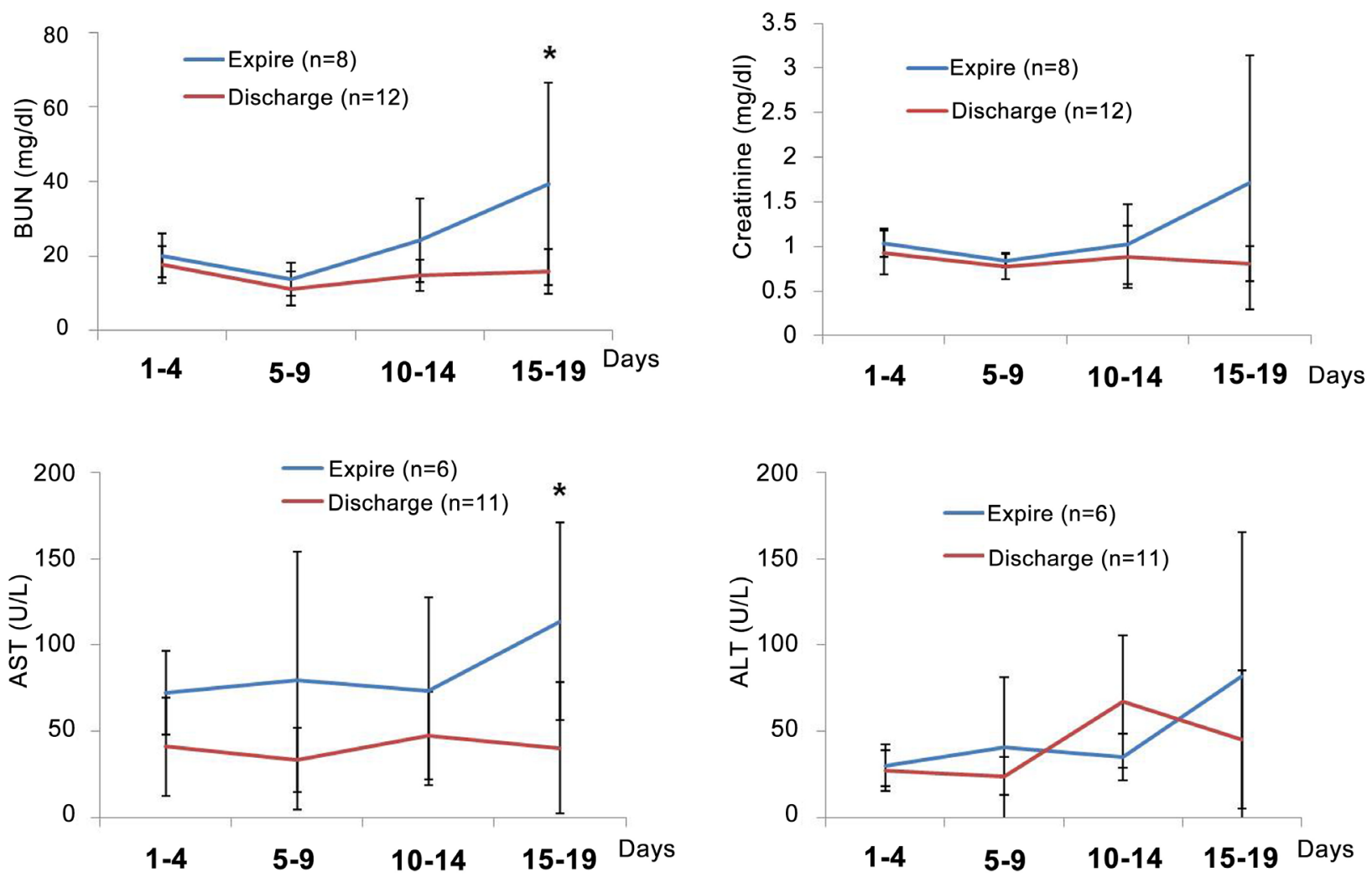

Figure 4. BUN, Creatinine, AST and ALT laboratory value of expire group/discharge group. Significant difference between expire group versus discharge group; ${ }^{\star} \mathrm{p}<0.05$.

Table 3. Odds ratio of death for each factor.

\begin{tabular}{cc}
\hline & $\begin{array}{c}\text { Odds ratio for death } \\
(95 \% \text { confidence interval })\end{array}$ \\
\hline TBSA $^{\mathrm{a}}$ & $1.085(1.028-1.145)$ \\
$\mathrm{ABSI}^{\mathrm{a}}$ & $1.884(1.190-2.983)$ \\
$\mathrm{NGAL}$ & $1.109(1.038-1.185)$ \\
$(\text { per } 10 \text { increase })^{\mathrm{a}}$ & \\
NGAL & $1.092(1.013-1.178)$ \\
\hline
\end{tabular}

${ }^{\mathrm{a}}$ Unadjusted odds ratio. ${ }^{\mathrm{b}}$ Adjusted for age, TBSA, ABSI.

BUN levels increased later. During the early stage after a burn injury, the mean levels of BUN and creatinine showed no significant difference between the discharged patients and the expired patients ( $\mathrm{p}$ value $=0.176,0.300$ ). Similar to serum NGAL levels, AST levels in the expired patients were higher than those in the discharged patients throughout the evaluation period ( $\mathrm{p}$ value $<0.001$ ). But ALT levels in both patients groups showed no significant difference.

\subsection{Comparison between NGAL Levels and ABSI in Patients with Severe Burns}

The initial severity of the burn patients was evaluated within 48 hours of the 
burn by comparing the levels of NGAL and ABSI. In some cases, the ABSI was higher in discharged patients than in the expired patients. However, serum NGAL levels were mostly higher in the expired patients than in the discharged patients (Supplement 1).

\section{Discussion}

A severe burn is a serious and complex injury that may result in disability and death. Thus, special methods for its diagnosis and treatment are required [20]. There have been several reports about the methods for evaluating mortality risk, but none of them have been adopted as a standard. Further, mortality rate is affected by factors such as age, sex, size of burn injury, respiratory damage, trauma, and pneumonia [21]. The ABSI and APACHE II score are used to compensate for the shortcomings of the current methods of diagnosis and prognosis of burn injuries; however, there is a need for more reliable and accurate methods. Therefore, in this study, we assessed whether NGAL levels could be used for diagnosis and prognosis of burn injuries.

We analyzed the severity of burn injuries in ICU patients by measuring the TBSA, ABSI, and serum NGAL level. We classified the ICU patients into discharged patients, including those that survived, and expired patients. The results showed that TBSA, ABSI, and serum NGAL level were higher in the expired patients than in the discharged patients. ABSI is reportedly a more accurate and useful tool than TBSA, but given the advancements in therapeutic techniques, treatments, and technologies that have increased the survival rate of patients aged $>60$ years and with burns involving $30 \%$ of the TBSA, the score for sex and age need to be revised [22]. Since we verified that serum NGAL level could accurately classify burn severity, we believe that serum NGAL level can be used as the only indicator for diagnosis. Our study showed that some patients with severe burns died, even though their ABSI was not high (Supplement 1). Therefore, we cannot conclude that the severity of burns increases with an increase in the ABSI. However, our findings suggested that serum NGAL level reflects the severity of burns more exactly than ABSI.

We additionally compared serum NGAL levels over time between the discharged patient and the expired patients. We found that as serum NGAL level decreased, the burn patients were moved to general wards or discharged, whereas if serum NGAL level remained high or increased, many patients died or stayed in the ICU for a long duration. Briefly, serum NGAL level allowed us to diagnose and provide a prognosis of burn patients to some extent.

On comparing the use of only TBSA and ABSI to determine the severity of burns in patients with respiratory damage, we noted that the severity was higher in patients with a high TBSA. However, serum NGAL level was higher in the patients with respiratory damage. Moreover, these patients died earlier than those without respiratory damage.

Severe burn injury damages several organs of the body [18]. For example, it results in renal dysfunction or decreased urine output in the kidney, which often 
accompanies uremia and multiple-organ dysfunction, thereby leading to a poor prognosis [23] [24] [25]. A few recent clinical studies reported that the plasma NGAL level allowed precise determination of AKI. According to one study, the NGAL level in the patients with progressive AKI rapidly increased 7 days after their admission to the hospital [17]. However, we verified that serum NGAL could be expressed within 48 hours of burn injury, which represents a systemic response including AKI and reflects the severity of the burn injury.

To determine the correlation between NGAL expression and other organ dysfunction in patients with severe burns, we analyzed blood chemistry. Our results showed that the AST and LDH levels increased more significantly in the expired patients than in the discharged patients with severe burns. As such, muscle damage, as well as liver and heart damage, might occur in the early stage.

Serum NGAL level as an early predictor of AKI might reflect the severity of burns and could also be used as an indicator of inflammation in burned children [26]. AKI occurred in approximately $26 \%$ (8 of 31 ) of patients and was associated with a mortality rate of $75 \%$ (6 of 8 ) in our study. The AKI rate (18\%) and the mortality rate in patients with AKI $(73 \%)$ in our study were similar to that in a previous report (24\% and $73 \%$, respectively) [18], but of the 14 subjects who died in our study, 6 (43\%) had AKI. Also, the NGAL level made no difference whether patients had AKI or not (AKI: non-AKI, $886 \pm 251.5: 770 \pm 161.6, \mathrm{p}=$ 0.325). NGAL is a good early biomarker of AKI and can predict the necessity of renal replacement therapy initiation [27]. Our data support this idea partially, but we also suggest that NGAL might reflect damage of various organs as well as the severity of burns.

NGAL is a major inflammatory protein [28] [29] and is expressed mainly in neutrophils. A previous study reported that the NGAL level increases in acute systemic inflammatory responses such as stroke, renal failure, or infection [30] [31] [32]. NGAL is expressed in epithelial cells, renal tubular cells, and hepatocytes in an inflammatory state [33] [34] [35]. Recently, NGAL was also found to be expressed in endothelial cells, smooth muscle cells, and macrophages in atherosclerotic plaques [36]. In addition, NGAL expression is observed in normal or pathological tissues of the human stomach, liver, kidney, and colon [37] [38]. NGAL performs various functions including induction of apoptosis [39], suppression of bacterial growth, and modulation of inflammatory responses [37] in addition to its protective functions against cold and heat stresses and $\mathrm{H}_{2} \mathrm{O}_{2}$ toxicity [14] [15] [16].

The relevance of CRP and NGAL in inflammatory conditions has been reported [26], and they are regarded as early markers of inflammation. Our results showed CRP levels in the expired patients were just a little higher than those of the discharged patients. A Correlation of NGAL and CRP was lower than AST, LDH and myoglobin $(r=0.331(0.069))$. Because CRP revealed acute inflammation at mostly patients with burn injury [40], there was not a great deal of difference in severe patients.

In epithelial cells the level of NGAL increases by the inflammatory state. The 
secretion of NGAL is greatly increased in cases of damaged epithelial cells of the kidneys, large intestine, liver, and lungs [41]. Meldrum et al. reported that nuclear factor- $\kappa \mathrm{B}$ was able to quickly activate epithelial cells following acute damage Severe burns may lead to an increase in inflammation, infection, and multipleorgan dysfunction due to decreased immunity as well as skin damage [17] [42]. The results of our study suggested that NGAL expression is high in severe burn patients with systemic diseases in the early stage, and the higher the NGAL level, the higher was the mortality rate.

There are several limitations in this study. Patients were included by convenience sampling and this study was performed with a relatively small number of patients. In addition, the study was only limited to adult patients with severe burn and therefore may not accurately reflect all burn patients. The small patients and limited sample tests may increase that the results are spurious. This report is a pilot study to help predict the severity of burns. Future studies with larger sample number sand better experimental strategies are needed to prove the value of NGAL as a good marker for predicting mortality.

\section{Conclusion}

Measurement of serum NGAL level together with ABSI and TBSA in the early stage of burns can help determine the condition of burn patients more accurately. In addition, the change in the NGAL level of burn patients during their hospital stay can appropriately represent the condition of such patients. Thus, we believe that serum NGAL level serves as a biomarker for burn patients within 72 hours of injury and can guide the provision of effective treatment for burn patients. Nonetheless, we may infer that NGAL expression is associated with the regeneration of damaged cells and tissues of organs such as the heart and liver, which should be further studied.

\section{Declaration of Interest}

The authors do not have any financial relationship with any companies that may have financial interest in the information provided by this manuscript.

\section{References}

[1] Baumann, H. and Gauldie, J. (1994) The Acute Phase Response. Immunology Today, 15, 74-80. https://doi.org/10.1016/0167-5699(94)90137-6

[2] Flower, D.R., North, A.C. and Sansom, C.E. (2000) The Lipocalin Protein Family: Structural and Sequence Overview. Biochimicaet Biophysica Acta (BBA)-Protein Structure and Molecular Enzymology, 1482, 9-24. https://doi.org/10.1016/S0167-4838(00)00148-5

[3] Church, D., Elsayed, S., Reid, O., Winston, B. and Lindsay, R. (2006) Burn Wound Infections. Clinical Microbiology Reviews, 19, 403-434. https://doi.org/10.1128/CMR.19.2.403-434.2006

[4] Orman, M.A., Nguyen, T.T., Ierapetritou, M.G., Berthiaume, F. and Androulakis, I.P. (2011) Comparison of the Cytokine and Chemokine Dynamics of the Early Inflammatory Response in Models of Burn Injury and Infection. Cytokine, 55, 362- 
371. https://doi.org/10.1016/j.cyto.2011.05.010

[5] Goetz, D.H., Holmes, M.A., Borregaard, N., Bluhm, M.E., Raymond, K.N. and Strong, R.K. (2002) The Neutrophil Lipocalin NGAL Is a Bacteriostatic Agent That Interferes with Siderophore-Mediated Iron Acquisition. Molecular Cell, 10, 10331043. https://doi.org/10.1016/S1097-2765(02)00708-6

[6] Flo, T.H., Smith, K.D., Sato, S., Rodriguez, D.J., Holmes, M.A., Strong, R.K., Akira, S. and Aderem, A. (2004) Lipocalin 2 Mediates an Innate Immune Response to Bacterial Infection by Sequestrating Iron. Nature, 432, 917-921. https://doi.org/10.1038/nature03104

[7] Zhang, J., Wu, Y., Zhang, Y., LeRoith, D., Bernlohr, D.A. and Chen, X. (2008) The Role of Lipocalin 2 in the Regulation of Inflammation in Adipocytes and macrophages. Molecular Endocrinology, 22, 1416-1426.

https://doi.org/10.1210/me.2007-0420

[8] Chakraborty, S., Kaur, S., Guha, S. and Batra, S.K. (2012) The Multifaceted Roles of Neutrophil Gelatinase Associated Lipocalin (NGAL) in Inflammation and Cancer. Biochimicaet Biophysica Acta (BBA)-Reviews on Cancer, 1826, 129-169. https://doi.org/10.1016/j.bbcan.2012.03.008

[9] Guo, H., Jin, D., Zhang, Y., Wright, W., Bazuine, M., Brockman, D.A., Bernlohr, D. A. and Chen, X. (2010) Lipocalin-2 Deficiency Impairs Thermogenesis and Potentiates Diet-Induced Insulin Resistance in Mice. Diabetes, 59, 1376-1385. https://doi.org/10.2337/db09-1735

[10] Jun, L.S., Siddall, C.P. and Rosen, E.D. (2011) A Minor Role for Lipocalin 2 in High-Fat Diet-Induced Glucose Intolerance. American Journal of Physiology-Endocrinology and Metabolism, 301, E825-E835. https://doi.org/10.1152/ajpendo.00147.2011

[11] Cruz, D.N., de Cal, M., Garzotto, F., Perazella, M.A., Lentini, P., Corradi, V., Piccinni, P. and Ronco, C. (2010) Plasma Neutrophil Gelatinase-Associated Lipocalin Is an Early Biomarker for Acute Kidney Injury in an Adult ICU Population. Intensive Care Medicine, 36, 444-451. https://doi.org/10.1007/s00134-009-1711-1

[12] Roudkenar, M.H., Kuwahara, Y., Baba, T., Roushandeh, A.M., Ebishima, S., Abe, S., Ohkubo, Y. and Fukumoto, M. (2007) Oxidative Stress Induced Lipocalin 2 Gene Expression: Addressing Its Expression under the Harmful Conditions. Journal of Radiation Research, 48, 39-44. https://doi.org/10.1269/jrr.06057

[13] Vemula, M., Berthiaume, F., Jayaraman, A. and Yarmush, M.L. (2004) Expression Profiling Analysis of the Metabolic and Inflammatory Changes Following Burn Injury in Rats. Physiological Genomics, 18, 87-98. https://doi.org/10.1152/physiolgenomics.00189.2003

[14] Roudkenar, M.H., Halabian, R., Ghasemipour, Z., Roushandeh, A.M., Rouhbakhsh, M., Nekogoftar, M., Kuwahara, Y., Fukumoto, M. and Shokrgozar, M.A. (2008) Neutrophil Gelatinase-Associated Lipocalin Acts as a Protective Factor against $\mathrm{H}_{2} \mathrm{O}_{2}$ Toxicity. Archives of Medical Research, 39, 560-566. https://doi.org/10.1016/j.arcmed.2008.05.003

[15] Roudkenar, M.H., Halabian, R., Roushandeh, A.M., Nourani, M.R., Masroori, N., Ebrahimi, M., Nikogoftar, M., Rouhbakhsh, M., Bahmani, P., Najafabadi, J. A. and Shokrgozar, M.A. (2009) Lipocalin 2 Regulation by Thermal Stresses: Protective Role of Lcn2/NGAL against Cold and Heat Stresses. Experimental Cell Research, 315, 3140-3151. https://doi.org/10.1016/j.yexcr.2009.08.019

[16] Borkham-Kamphorst, E., van de Leur, E., Zimmermann, H.W., Karlmark, K.R., Tihaa, L., Haas, U., Tacke, F., Berger, T., Mak, T.W. and Weiskirchen, R. (2013) Protective Effects of Lipocalin-2 (LCN2) in Acute Liver Injury Suggest a Novel Func- 
tion in Liver Homeostasis. Biochimica et Biophysica Acta, 1832, 660-673. https://doi.org/10.1016/j.bbadis.2013.01.014

[17] Hong, D.Y., Lee, J.H., Park, S.O., Baek, K.J. and Lee, K.R. (2013) Plasma Neutrophil Gelatinase-Associated Lipocalin as Early Biomarker for Acute Kidney Injury in Burn Patients. Journal of Burn Care and Research, 34, e326-e332. https://doi.org/10.1097/bcr.0b013e31827d1f36

[18] Monafo, W.W. and Bessey, P. (1993) Pathophysiology of Burn Shock. In: Rylah, L., Ed., Critical Care of the Burned Patient, Cambridge University Press, Cambridge, $1-14$.

[19] Anlatıc1, R., Özerdem, Ö.R., Dalay, C., Kesiktaş, E., Acartürk, S. and Seydaoğlu, G. (2002) A Retrospective Analysis of 1083 Turkish Patients with Serious Burns: Part 2: Burn Care, Survival and Mortality. Burns, 28, 239-243.

https://doi.org/10.1016/S0305-4179(02)00030-X

[20] Devarajan, P. (2010) Neutrophil Gelatinase-Associated Lipocalin: A Promising Biomarker for Human Acute Kidney Injury. Biomarkers, 4, 265-280. https://doi.org/10.2217/bmm.10.12

[21] Gokdemir, M.T., Aldemir, M., Sogut, O., Guloglu, C., Sayhan, M.B., Orak, M. and Ustundag, M. (2012) Clinical Outcome of Patients with Severe Burns Presenting to the Emergency Department. Journal of Current Surgery, 2, 17-23. https://doi.org/10.4021/jcs19e

[22] Forster, N.A., Zingg, M., Haile, S.R., Künzi, W., Giovanoli, P. and Guggenheim, M. (2011) 30 Years Later-Does the ABSI Need Revision? Burns, 37, 958-963. https://doi.org/10.1016/j.burns.2011.03.009

[23] Mustonen, K.M. and Vuola, J. (2008) Acute Renal Failure in Intensive Care Burn Patients (ARF in Burn Patients). Journal of Burn Care and Research, 29, 227-237. https://doi.org/10.1097/BCR.0b013e31815f3196

[24] Holm, C., Hörbrand, F., von Donnersmarck, G.H. and Mühlbauer, W. (1999) Acute Renal Failure in Severely Burned Patients. Burns, 25, 171-178. https://doi.org/10.1016/S0305-4179(98)00144-2

[25] Chrysopoulo, M.T., Jeschke, M.G., Dziewulski, P., Barrow, R.E. and Herndon, D.N. (1999) Acute Renal Dysfunction in Severely Burned Adults. Journal of Trauma and Acute Care Surgery, 46, 141-144. https://doi.org/10.1097/00005373-199901000-00024

[26] Yavuz, S., Anarat, A., Acartürk, S., Dalay, A.C., Kesiktas, E., Yavuz, M. and Acartürk, T.O. (2014) Neutrophil Gelatinase Associated Lipocalin as an Indicator of Acute Kidney Injury and Inflammation in Burned Children. Burns, 40, 648-654. https://doi.org/10.1016/j.burns.2013.09.004

[27] Haase, M., Bellomo, R., Devarajan, P., Schlattmann, P., Haase-Fielitz, A. and Group, N. (2009) Accuracy of Neutrophil Gelatinase-Associated Lipocalin (NGAL) in Diagnosis and Prognosis in Acute Kidney Injury: A Systematic Review and MetaAnalysis. American Journal of Kidney Diseases, 54, 1012-1024. https://doi.org/10.1053/j.ajkd.2009.07.020

[28] Kjeldsen, L., Johnsen, A.H., Sengeløv, H. and Borregaard, N. (1993) Isolation and Primary Structure of NGAL, A Novel Protein Associated with Human Neutrophil Gelatinase. Journal of Biological Chemistry, 268, 10425-10432.

[29] Bundgaard, J.R., Sengelov, H., Borregaard, N. and Kjeldsen, L. (1994) Molecular Cloning and Expression of a cDNA Encoding NGAL: A Lipocalin Expressed in Human Neutrophils. Biochemical and Biophysical Research Communications, 202, 1468-1475. https://doi.org/10.1006/bbrc.1994.2096

[30] Elneihoum, A.M., Falke, P., Axelsson, L., Lundberg, E., Lindgärde, F. and Ohlsson, 
K. (1996) Leukocyte Activation Detected by Increased Plasma Levels of Inflammatory Mediators in Patients with Ischemic Cerebrovascular Diseases. Stroke, 27, 1734-1738. https://doi.org/10.1161/01.STR.27.10.1734

[31] Mishra, J., Ma, Q., Prada, A., Mitsnefes, M., Zahedi, K., Yang, J., Barasch, J. and Devarajan, P. (2003) Identification of Neutrophil Gelatinase-Associated Lipocalin as a Novel Early Urinary Biomarker for Ischemic Renal Injury. Journal of the American Society of Nephrology, 14, 2534-2543. https://doi.org/10.1097/01.ASN.0000088027.54400.C6

[32] Mishra, J., Dent, C., Tarabishi, R., Mitsnefes, M.M., Ma, Q., Kelly, C., Ruff, S.M., Zahedi, K., Saho, M., Bean, J., Mori, K., Barasch, J. and Devarajan, P., (2005) Neutrophil Gelatinase-Associated Lipocalin (NGAL) as a Biomarker for Acute Renal Injury after Cardiac Surgery. The Lancet, 365, 1231-1238.

https://doi.org/10.1016/S0140-6736(05)74811-X

[33] Gwira, J.A., Wei, F., Ishibe, S., Ueland, J.M., Barasch, J. and Cantley, L.G. (2005) Expression of Neutrophil Gelatinase-Associated Lipocalin Regulates Epithelial Morphogenesis in Vitro. Journal of Biological Chemistry, 280, 7875-7882.

https://doi.org/10.1074/jbc.M413192200

[34] Cowland, J.B., Sørensen, O.E., Sehested, M. and Borregaard, N. (2003) Neutrophil Gelatinase-Associated Lipocalin Is Up-Regulated in Human Epithelial Cells by IL-1 $\beta$, but Not by TNF- $\alpha$. The Journal of Immunology, 171, 6630-6639. https://doi.org/10.4049/jimmunol.171.12.6630

[35] Jayaraman, A., Roberts, K.A., Yoon, J., Yarmush, D.M., Duan, X., Lee, K. and Yarmush, M.L. (2005) Identification of Neutrophil Gelatinase-Associated Lipocalin (NGAL) as a Discriminatory Marker of the Hepatocyte-Secreted Protein Response to IL-1 $\beta$ : A Proteomic Analysis. Biotechnology and Bioengineering, 91, 502-515. https://doi.org/10.1002/bit.20535

[36] Hemdahl, A.L., Gabrielsen, A., Zhu, C., Eriksson, P., Hedin, U., Kastrup, J., Thoren, P. and Hansson, G.K. (2006) Expression of Neutrophil Gelatinase-Associated Lipocalin in Atherosclerosis and Myocardial Infarction. Arteriosclerosis, Thrombosis, and Vascular Biology, 26, 136-142. https://doi.org/10.1161/01.ATV.0000193567.88685.f4

[37] Cowland, J.B. and Borregaard, N. (1997) Molecular Characterization and Pattern of Tissue Expression of the Gene for Neutrophil Gelatinase-Associated Lipocalin from Humans. Genomics, 45, 17-23. https://doi.org/10.1006/geno.1997.4896

[38] Friedl, A., Stoesz, S.P., Buckley, P. and Gould, M.N. (1999) Neutrophil GelatinaseAssociated Lipocalin in Normal and Neoplastic Human Tissues. Cell Type-Specific Pattern of Expression. The Histochemical Journal, 31, 433-441. https://doi.org/10.1023/A:1003708808934

[39] Devireddy, L.R., Teodoro, J.G., Richard, F.A. and Green, M.R. (2001) Induction of Apoptosis by a Secreted Lipocalin That Is Transcriptionally Regulated by IL-3 Deprivation. Science, 293, 829-834. https://doi.org/10.1126/science.1061075

[40] Van de Goot, F., Krijnen, P.A., Begieneman, M.P., Ulrich, M.M., Middelkoop, E. and Niessen, H.W. (2009) Acute Inflammation Is Persistent Locally in Burn Wounds: A Pivotal Role for Complement and C-Reactive Protein. Journal of Burn Care and Research, 30, 274-280. https://doi.org/10.1097/BCR.0b013e318198a252

[41] Helanova, K., Spinar, J. and Parenica, J. (2014) Diagnostic and Prognostic Utility of Neutrophil Gelatinase-Associated Lipocalin (NGAL) in Patients with Cardiovascular Diseases-Review. Kidney and Blood Pressure Research, 39, 623-629. https://doi.org/10.1159/000368474

[42] Meldrum, K.K., Hile, K., Meldrum, D.R., Crone, J.A., Gearhart, J.P. and Burnett, 
A.L. (2002) Simulated Ischemia Induces Renal Tubular Cell Apoptosis through a Nuclear Factor $-\kappa$ B Dependent Mechanism. The Journal of Urology, 168, 248-252. https://doi.org/10.1016/S0022-5347(05)64902-6

Supplement 1. Comparison survival Between in order of ABSI \& NGAL scores.

\begin{tabular}{|c|c|c|c|c|c|c|c|}
\hline \multicolumn{4}{|c|}{ In Order of ABSI } & \multicolumn{4}{|c|}{ In Order of NGAL } \\
\hline Age & ABSI & NGAL & Survival & Age & ABSI & NGAL & Survival \\
\hline $\mathrm{M} / 42$ & 14 & 763 & Expired & $\mathrm{M} / 31$ & 9 & 1159 & Expired \\
\hline $\mathrm{M} / 61$ & 13 & 1104 & Expired & $\mathrm{M} / 53$ & 8 & 1105 & Expired \\
\hline $\mathrm{M} / 25$ & 12 & 896 & Expired & $\mathrm{M} / 61$ & 13 & 1104 & Expired \\
\hline $\mathrm{M} / 33$ & 12 & 615 & Expired & $\mathrm{M} / 21$ & 6 & 998 & Expired \\
\hline $\mathrm{M} / 46$ & 12 & 800 & Expired & $\mathrm{M} / 25$ & 12 & 896 & Expired \\
\hline $\mathrm{M} / 69$ & 12 & 481 & Discharged & $\mathrm{M} / 55$ & 11 & 875 & Expired \\
\hline $\mathrm{M} / 36$ & 11 & 685 & Expired & $\mathrm{M} / 46$ & 12 & 800 & Expired \\
\hline $\mathrm{M} / 21$ & 11 & 777 & Expired & $\mathrm{M} / 39$ & 9 & 792 & Discharged \\
\hline $\mathrm{M} / 40$ & 11 & 749 & Expired & $\mathrm{M} / 21$ & 11 & 777 & Expired \\
\hline $\mathrm{M} / 55$ & 11 & 875 & Expired & $\mathrm{M} / 42$ & 14 & 763 & Expired \\
\hline$F / 81$ & 10 & 661 & Expired & $\mathrm{M} / 43$ & 9 & 762 & Discharged \\
\hline $\mathrm{M} / 43$ & 10 & 482 & Discharged & $\mathrm{M} / 40$ & 11 & 749 & Expired \\
\hline $\mathrm{M} / 65$ & 10 & 442 & Discharged & $\mathrm{M} / 36$ & 11 & 685 & Expired \\
\hline $\mathrm{M} / 49$ & 10 & 365 & Discharged & $\mathrm{F} / 81$ & 10 & 661 & Expired \\
\hline $\mathrm{M} / 41$ & 9 & 407 & Expired & $\mathrm{M} / 33$ & 12 & 615 & Expired \\
\hline $\mathrm{M} / 31$ & 9 & 1159 & Expired & $\mathrm{M} / 31$ & 4 & 580 & Discharged \\
\hline $\mathrm{M} / 43$ & 9 & 762 & Discharged & $\mathrm{M} / 43$ & 10 & 482 & Discharged \\
\hline $\mathrm{M} / 39$ & 9 & 792 & Discharged & $\mathrm{M} / 69$ & 12 & 481 & Discharged \\
\hline $\mathrm{M} / 45$ & 9 & 421 & Discharged & $\mathrm{M} / 54$ & 8 & 452 & Discharged \\
\hline $\mathrm{M} / 53$ & 8 & 1105 & Expired & $\mathrm{M} / 65$ & 10 & 442 & Discharged \\
\hline $\mathrm{F} / 59$ & 8 & 329 & Discharged & $\mathrm{M} / 21$ & 4 & 430 & Discharged \\
\hline $\mathrm{M} / 54$ & 8 & 452 & Discharged & $\mathrm{M} / 45$ & 9 & 421 & Discharged \\
\hline $\mathrm{M} / 22$ & 7 & 356 & Discharged & $\mathrm{M} / 41$ & 9 & 407 & Expired \\
\hline $\mathrm{M} / 52$ & 7 & 224 & Discharged & $\mathrm{M} / 51$ & 6 & 392 & Discharged \\
\hline $\mathrm{M} / 21$ & 6 & 998 & Expired & $\mathrm{F} / 47$ & 6 & 386 & Discharged \\
\hline $\mathrm{M} / 41$ & 6 & 273 & Discharged & $\mathrm{M} / 49$ & 10 & 365 & Discharged \\
\hline $\mathrm{F} / 47$ & 6 & 386 & Discharged & $\mathrm{M} / 22$ & 7 & 356 & Discharged \\
\hline$F / 31$ & 6 & 168 & Discharged & $\mathrm{F} / 59$ & 8 & 329 & Discharged \\
\hline $\mathrm{M} / 51$ & 6 & 392 & Discharged & $\mathrm{M} / 41$ & 6 & 273 & Discharged \\
\hline $\mathrm{M} / 21$ & 4 & 430 & Discharged & $\mathrm{M} / 52$ & 7 & 224 & Discharged \\
\hline $\mathrm{M} / 31$ & 4 & 580 & Discharged & $\mathrm{F} / 31$ & 6 & 168 & Discharged \\
\hline
\end{tabular}


Submit or recommend next manuscript to SCIRP and we will provide best service for you:

Accepting pre-submission inquiries through Email, Facebook, LinkedIn, Twitter, etc. A wide selection of journals (inclusive of 9 subjects, more than 200 journals)

Providing 24-hour high-quality service

User-friendly online submission system

Fair and swift peer-review system

Efficient typesetting and proofreading procedure

Display of the result of downloads and visits, as well as the number of cited articles Maximum dissemination of your research work

Submit your manuscript at: http://papersubmission.scirp.org/

Or contact jbm@scirp.org 